\title{
ANALISIS BAHASA GAUL DALAM NOVEL AYAT AMAT CINTA KARYA ASMA NADIA, BOIM LEBON, FAHRI ASIZAH, BIRULAUT-TAUFAN E. PRAST, LIAN KAGURA, REX- RATNO FADILLAH
}

\author{
Kurniady Wijaya dan Pheni Cahya Kartika \\ Pendidikan Bahasa dan Sastra Indonesia, Universitas Muhammdiyah Surabaya \\ Kurniadywijaya.pbsi@gmail.com
}

\begin{abstract}
ABSTRAK
Novel ayat amat cinta karya asma Nadia, Boim Lebon dkk Menampilkan bahasa gaul guna menyesuaikan dengan kondisi peminat nya terutama remaja. Berdasarkan penelitian bahasa telah banyak mengalami pergeseran yang signifikan atas bahasa yang di ciptakan hendaknya dapat menciptakan bahasa gaul yang sewajarnya sehingga tidak mengacaukan komunikasi pendidikan bahasa Indonesia. Proses morfologis ini hanya di batasi pada afiksasi reduplikasi, dan pemendekan kata yang terdapat pada novel ayat amat cinta karya asma Nadia, Boim Lebon dkk. Sebagai data penelitian, data ini berbentuk kosakata bahasa gaul dalam novel ayat amat cinta karya asma Nadia, Boim Lebon dkk. Penelitian ini menggunakan penelitian deskriptif kualitatif. Dengan teknik dasar membaca dan mencatat. Dengan teknik analisis interaktif dengn tahapan reduksi, penyajian, dan penarikan kesimpulan. Berdasarkan hasil penelitian dalam novel ayat amat cinta karya asma Nadia, Boim Lebon dkk tersebut telah banyak mengalami pergeseran yang signifikan pada objek penelitian yang diteliti. Oleh karena hal tersebut, peneliti mengharapkan adanya kesadaran sehingga tidak mengacaukan komunikasi pendidikan terutama bahasa indonesia.
\end{abstract}

Kata kunci: bahasa gaul, kata, morfologis

\begin{abstract}
Novel entitled Ayat Amat Cinta written by Asma Nadia and the associate is a collection of funny stories whose characters are always named with verses of Koran. The novel uses slang language to follow the readers who are mostly from teenagers. Based on language research, many have experienced a significant shift in the language creation and therefore should produce an appropriate slang language so as not to disrupt Indonesian education communication. This morphological process was limited to the reduplication of affixation, and the shortening of words. The data were in the forms of slang vocabularies in the novel of Ayat Ayat Cinta. This study used a descriptive qualitative researchusing the basic techniques of reading and recording. Likewise, this study usedinteractive analysis technique with three stages: reduction, presentation, and conclusion. The result revealed that there were considerable language shifts in Ayat Ayat Cinta. Therefore, it is expected that the awareness not to disrupt education communication, especially Indonesian is mushroomed.
\end{abstract}

Keywords: slang language, word, morphological 


\section{PENDAHULUAN}

Penggunaan bahasa sebagai fungsi dasar yang tidak berhubungan dengan status dan nilai sosial adalah bahasa sebagai alat komunikasi secara langsung baik tertulis atau lisan (muslich, 2010:27). Dalam komunikasi, bahasa merupakan media utama meskipun terdapat aspek pendukung komunikasi yang lain seperti ekspresi dan gerak tubuh. Bahasa dapat menggambarkan kecendrungan masyarakat penuturnya. Belajar secara tidak langsung akan belajar mengenal masyarakat penuturnya.

Anak muda merupakan anak yang cenderung mengakui bahwa dirinya memiliki kebebasan dan sikap tidak mau peduli terhadap aturan formal.Mereka cenderung berbuat sesuka hati mereka.Maka tidak salah banyak orang yang menyatakan bahwa anak muda identik dengan aktivitasnya mencari kesenangan.Hal seperti ini bisa dilihat di waktu luang terutama waktu liburan sekolah misalnya, model, pesta, seni musik yang mereka gemari.

Pola pikir dan tingkah laku remaja saat ini telah banyak meniru gaya selebritis yang setiap hari mereka lihat di majalah maupun media alektronik lainnya seperti televisi. peniruan selebriiti tersebut bukan hanya penampilan semata melainkan keseluruhan Potensi dalam diri remaja yang memungkinkan mereka dapat mengembangkan penampilan citra diri tertentu, salah satunya adalah pada penggunaan bahasa.

Masyarakat pada saat ini sering berkomunikasi dengan menggunakan bahasa gaul. Dalam Kamus Besar Bahasa Indonesia (2008: 116), disebutkan bahwa bahasa gaul merupakan bahasa Indonesia nonformal yang digunakan oleh komunitas tertentu atau di daerah tertentu untuk pergaulan. Bahasa gaul tidak hanya dipakai oleh para remaja, tetapi juga digunakan oleh orang-orang dewasa. Bahasa gaul dianggap lebih modern daripada bahasa Indonesia atau bahasa daerah. Penggunanya pun akan dikatakan sebagai orang yang modern. Hal ini dapat kita pahami karena bahasa gaul lahir dari masyarakat perkotaan yang modern sehingga penggunanya pun akan dikatakan sebagai orang kota yang modern.

Bahasa yang digunakan remaja saat ini popular dengan istilah bahasa gaul (bahasa pergaulan).Bahasagaul, awalnya berasal dari bahasa slang dan bahasa prokem. Bahasa slang merupakan salah satu bahasa yang digunakan kelompok remaja ketika mereka sedang duduk di warung kopi, kantin dan tempat lain yang mereka 
jadikan tempat kumpul dan bersenang-senang.bahasa slang bersifat lelucon atau humor. Menurut Eric Partridge (dalam Moentaha,2006:195), slang merupakan bahasa percakapan, ketimbang bahasa standart. Sedangkan didalam kamus webster'sNew Dictionary Of The American Language (dalam Moentaha, 2006:195) mencatat bahwa slang berkembang dari upaya untuk menemukan ungkapan-ungkapan yang segar, kuat, humoris yang mengandung nuansa ekspresif dan pada umumnya ada yang menghilang dari pemakaian atau datang untuk memiliki status yang lebih formal berbeda dengan pernyataan Wentworth dan Flexner (dalam Moentaha, 2006:195) bahwa slang dipakai untuk menghindari kejenuhan kata-kata standart dan rutinitas kehidupan sehari-hari, sehingga dengan menggunakan bahasa slang kehidupan tampak lebih segar.

Berbeda dengan slang, bahasa prokem berasal dari kalangan pinggiran seperti pencopet, pencuri, tukang jambret, dan kaum homo seksual (waria). Bahasa ini digunakan sebagai bahasa rahasia yang hanya diketahui kelompok tersebut. Istilah prokem itu kemudian digunakan untuk menyebut bahasa yang digunakan pencoleng untuk berkomunikasi dengan sesama kaumnya sebagai bahasa rahasia (Sumarsono dan Paina, 2014:154). Secara perlahan bahasa ini juga merambah pada kalangan remaja terutama di kota-kota besar. Misalnya kata ember (emang benar) yang lumrah digunakan kaum waria sekarang telah banyak digunakan oleh remaja lebih luas. Kata ember yang asalnya berbentuk kata benda berubah menjadi kata keterangan dari kata sifat dan maknanya pun berubah dari makna yang sebenarnya, makna yang sebenarnya ember adalah wadah tempat air sedangkan ember dalam bahasa prokem maknanya emang benar (memang benar). Dengan demikian, pengaruh bahasa slang dan prokem memunculkan istilah bahasa gaul dikalangan remaja.

Pembentukan kata dalam bahasa gaul menurut proses linguistik dapat melalui beberapa proses yang biasanya disebut dengan gejala bahasa meliputi perubahan, penambahan, penghilangan, perpindahan, pembalikan bunyi, dan perulangan (Wijana, 2010:25). Istilah bokap mengacu pada kata ayah atau bapak dalam bahasa baku. Pembentukan kata bokap melalui proses pembalikan huruf konsonan kemudian huruf vokal pertama diganti dengan huruf "o".

Istilah lain bahasa yang digunakan anak remaja ada yang menyebutkan bahasa ABG (anak baru gede). Bahasa ABG ini cenderung menggunakan bahasa santai atau 
bahasa sehari-hari penduduk saat bersantai dan bekumpul dengan teman sebaya, jadi bahasa yang digunakan tidak terlalu baku. Ketidak bakuan bahasa tersebut tercermin dalam kosa kata struktur kalimat dan intonasi. Misalkan kosa kata PD (percaya diri).

Bahasa akan terus berkembang dan memiliki aneka ragam atau variasi, baik berdasarkan kondisi sosiologis maupun kondisi psikologis dari penggunanya. Apa pun dan di manapun bahasa tersebut digunakan, akan selalu terus mengalami perubahan. Bahasa di suatu tempat akan berbeda penggunaannya di tempat yang lain. dan makna dari symbol-simbol bahasa tersebut juga akan terus mengalami perubahan seiring dengan berjalannya waktu terutama pada bahasa dialek ataupun bahasa tidak baku. Oleh karena itu, dikenal ada variasi atau ragam bahasa.ragam bahasa pedagang, ragam bahasa pejabat, ragam bahasa intelektual, ragam bahasa anak-anak, termasuk ragam bahasa gaul.

Variasi bahasa yang digunakan anak muda tidak hadir sebagai bahasa, tapi karena kebutuhan suatu kelompok masyarakat. Kelahiran dan perkembangan bahasa gaul bukan saja merupakan peristiwa sosial, tetapi lebih sebagai gejala sosial. Gejala tersebut tidak boleh dianggap remeh, tetapi justru perlu diamati sebagai akibat dan cerminan dari suatu kenyataan sosial.

Penyebaran penggunaan bahasa gaul banyak dipengaruhi oleh media-media seperti pada sinetron, film, acara-acara televisi, media sosial, termasuk juga pada media cetak seperti novel, cerpen dan majalah. Penggunaan bahasa tersebut popular digunakan oleh kalangan muda karena dipandang sebagai penunjuk identitas, eksistensi diri tentang kemajuan jaman.

Wujud nyata cerminan sosial bahasa gaul mulai banyak di surat kabar, majalah, bahkan sekarang sudah banyak cerita-cerita remaja yang diterbitkan. Pengaruh bahasa gaul terhadap pemakaian bahasa yang digunakan dalam cerita-cerita remaja menunjukkan bahwa cerita-cerita remaja saat ini memiliki potensi yang sangat besar terhadap perubahan dan pergeseran bahasa indonesia.untuk itu remaja perlu perhatian yang besar dan penelitian yang intensif, dengan demikian akan menjamin kelangsungan kebakuan bahasa indonesia. Pada sisi yang berbeda, kosa kata bahasagaul juga akan memperkaya kosakata bahasa indonesia dan akan menjadi sumber kata baru dalam mengembangkan dan melakukan pembinaan bahasa yang baik dan benar. 
Peneliti tertarik untuk melakukan penelitian pada Novel Ayat Amat cinta karya Asma Nadia, Boim Lebon dkk. Buku ini merupakan buku yang berisi kumpulan cerita-cerita lucu yang merupakan pelesetan dari novel remaja populer yang berjudul Ayat-Ayat Cinta. Penyajian dialog yang beraneka ragam dengan menggunakan bahasa gaul. Bahasa gaul pada buku tersebut memiliki ciri tersendiri yaitu dalam struktur dalam pembentukan kosakatanya lebih unik dan komunikatif. Hal lain juga terdapat kejanggalan dan perbedaan dengan ragam bahasa baku indonesia terutama dalam afiksasi dan pemendekan kata. Semisal pembentukan bahasa gaul dalam afiksasi yang terdapat dalam novel Ayat Amat Cinta karya Asma Nadia, Boim Lebon, dkk, yaitu perubahan prefiks $\{$ ter- $\}$ menjadi $\{$ ke- $\}$ pada kata terpilih, sehingga terpilih bentuk gaulnya menjadi kepilih, perubahan prefiks $\{$ ber- $\}$ menjadi $\{$ be- $\}$, seperti bergadang menjadi bergadang. Berikut pula terdapat pembentukan pemajemukan dan pemendekan kata bahasa gaul dalam novel Ayat Amat Cinta tersebut seperti kata cekikikan menjadi cekakak-cekikik dan sebagainya. Untuk itu maka peneneliti mengambil judul analisis bahasa gaul dalam novel Ayat Amat Cinta karya Asma Nadia, Boim Lebon dkk.

\section{METODE PENELITIAN}

Peneliti menggunakan penelitian deskriptif kulitatif. Penelitian kulitatif adalah penelitian yang bermaksud untuk memahami fenomena tentang apa yang dialami oleh subjek penelitian secara deskriptif dalam bentuk kata-kata dan bahasa (Moleong,2011:6). Penelitian deskriptif bertujuan membuat gambaran tentang sesuatu keadaan secara objektif, sehingga penelitian ini dilakukan atas fakta atau fenomena yang ada sebagai hasil karya manusia. Data yang akan diolah dan dipilih dari semua data yang sudah terkumpul sesuai dengan tujuan penelitian, termasuk mengkaji dan menganalisis semua data yang mendeskripsikan rumusan masalah yang telah ditetapkan.

Metode penelitian deskriptif adalah metode yang paling sederhana dan banyak dilakukan oleh peneliti.Penelitian deskriptif kualitatif ini mendeskripsian secara rinci dan mendalam tentang kondisi yang sebenarnya terjadi. Tujuanpenelitian ini adalah menggambarkan peristiwa pembentukan kata menganalisis perubahan kata yang terjadi dalam proses morfologi bahasa gaul dalam novel Ayat Amat Cinta karya Asma 
nadia, Boim Lebon dkk. Dalam penelitian ini menggunakan penelitian deskriptif kualitatif, sehingga setelah dianalisis dapat menemukan kajian objektif dari penelitian novel Ayat Amat Cinta Karya Asma Nadia, Boim Lebon dkk.

Teknik analisis data yang digunakan dalam penelitian ini yaitu teknik analisis interaktif.analisis data model interaktif Miles dan Huberman menjelaskan bahwa dalam melakukan analisis data kualitatif dapat dilakukan bersamaan dengan proses pengumpulan data. Proses yang bersamaan tersebut meliputi: 1) reduksi data, 2) penyajian data, dan 3) penarikan kesimpulan.

Teknik analisis data yang digunakan dalam penelitian ini yaitu teknik analisis interaktif.analisis data model interaktif Miles dan Huberman menjelaskan bahwa dalam melakukan analisis data kualitatif dapat dilakukan bersamaan dengan proses pengumpulan data. Proses yang bersamaan tersebut meliputi:1) reduksi data, 2) penyajian data, dan 3) penarikan kesimpulan.

Sugiyono (2014:247-253) menjelaskan langkah-langkah dalam menganalisis novel Ayat Amat Cinta karya Asma Nadia, Boim Lebon dkk dengan cara sebagai berikut: (1) Reduksi data adalah teknik pengelompokan data yang sesuai dengan kategori tertentu. Memilih suatu pokok penting yang menjadi fokus penelitian. Data yang diperoleh melalui hasil kegiatan membaca secara cermat dan dicatat dalam hal afiksasi, reduplikasi, pemendekan kata yang terdapat pada novel Ayat Amat Cinta karya Asma Nadia, Boim Lebon dkk. (2) Penyajian data adalah suatu teknik penyajian data dengan bentuk tabel, yang didalamnya tersaji data-data kategorisasi. Penelitian ini terdapat hal-hal pokok yang disajikan dalam deskripsi data. Hal ini bertujuan memberikan kemudahan dalam pembahasan secara menyeluruh terhadap masalah yang telah ditentukan dalam rumusan masalah. (3) Penarikan kesimpulan adalah memaknai atau mengartikan, menyimpulkan, dan deskripsikan data-data yang sebelumnya dan ditemukan dalam novel.

\section{PEMBAHASAN}

Berdasarkan penelitian terhadap bahasa gaul dalam novel ayat amat cinta karya Asma Nadia, Boim Lebon, dkk., diperoleh hasil penelitian berupa wujud kosakata bahasa gaul dengan hasil analisis Proses morfologis (pembentukan kata) bahasa gaul dalam Novel ayat amat cinta karya Asma Nadia, Boim Lebon, dkk. Sebagai berikut. 


\section{Afiksasi}

Afiks yang dipakai dalam afiksasi pada Novel ayat amat cinta karya Asma Nadia, Boim Lebon Dkk adalah afiks dalam bentuk kata karja aktif dan kata kerja pasif.

\section{Afiksasi Bahasa Gaul Bentuk KD + $\{-$ in $\}$}

Ditemukan perubahan afiks pada proses afiksasi pada bahasa gaul dalam novel Ayat Amat Cinta karya Asma Nadia, Boim Lebon dkk. Terdapat perubahan pada sufik yang seharusnya $\{-k a n\}$ menjadi $\{-i n\}$ selain itu beberapa kosakata disertai perubahan pada fonem $a$ menjadi fonem $e$ dalam bahasa gaul. seperti berikut.

Mau ngelakuin apa-apa, lakuin aja! Itu kuncinya! (KD. AAMC/hal.17)

Pada data di atas kata lakuin merupakan bahasa gaul dari kata lakukan yang berasal dari kata dasar laku, proses afiksasi yang seharusnya adalah kata dasar mendapat imbuhan -kan \{laku+-kan\} lakukan berubah menjadi kata dasar mendapat imbuhan -in \{laku+-in\} lakuin. Jadi, bentuk perubahan dalam bahasa gaul terdapat pada sufiks yang seharusnya $\{-$ kan $\}$ menjadi $\{$-in $\}$.

Keponakan dari mana? Kok ayat belum kenal, kenalin dong! (KD.AAMC/hal.18)

Pada data di atas, kata kenalin merupakan bahasa gaul dari kata kenalkan. Kata tersebut berasal dari kata dasar kenal, proses afiksasi yang seharusnya adalah kata dasar mendapat imbuhan -kan $\{$ kenal $+-k a n\}$. Kenalkan berubah menjadi kata dasar mendapat imbuhan -in $\{$ kenal+ -in $\}$ kenalin. Jadi bentuk perubahan dalam bahasa gaul terdapat pada sufiks yang seharusnya $\{-k a n\}$ menjadi $\{-i n\}$.

\section{Afiksasi Bahasa gaul $\{n-\}$ KD}

Terdapat perubahan pada prefiks yang seharusnya $\{$ men- $\}$ menjadi $\{n-\}$. Selain itu beberapa kosakata disertai perubahan pada fonem $a$ menjadi fonem $e$ dalam bahasa gaul.

Gue melotot, dalam imajinasi malah udah nonjok si darang sampai babak belur. (KD.AAMC/hal.14) 
Pada data di atas, kata nonjok merupakan bahasa gaul dari kata menonjok yang berasal dari kata tonjok, proses afiksasi yang seharusnya adalah dasar mendapat imbuhan prefiks men- $\{$ men- + tonjok\} menonjok berubah menjadi kata dasar mendapat imbuhan prefiks $n-\{\mathrm{n}-+$ tonjok $\}$ nonjok. Jadi, bentuk perubahan dalam bahasa gaul terdapat pada prefiks yang seharusnya berimbuhan $\{$ men- $\}$ berubah menjadi $\{n-\}$ pada bahasa gaul.

Harusnya gue bisa manfaatin momen itu kan? bilang hei... kek nanggung udah beradu pandang. (KD.AAC/hal.22)

Pada data di atas, kata nanggung merupakan bahasa gaul dari kata menanggung berasal dari kata tanggung, proses afiksasi yang seharusnya adalah dasar mendapat imbuhan prefiks men- $\{$ men- + tanggung $\}$ menanggung berubah menjadi kata dasar mendapat imbuhan prefiks $n-\{n-+$ tanggung $\}$ nanggung. Jadi, bentuk perubahan dalam bahasa gaul terdapat pada prefiks yang seharusnya berimbuhan $\{$ men- $\}$ berubah menjadi $\{n-\}$ pada bahasa gaul.

\section{Afiksasi bahasa gaul $\{$ ng- $\}+$ KD}

Ditemukan perubahan afiks pada proses afiksasi pada bahasa gaul dalam novel Ayat Amat Cinta karya Asma Nadia, Boim Lebon dkk. Terdapat perubahan pada prefiks yang seharusnya $\{$ men- $\}$ menjadi $\{n g-\}$ selain itu beberapa kosakata disertai perubahan pada fonem $a$ menjadi fonem $e$ dalam bahasa gaul, seperti berikut:

Bams terdiam sejenak, lalu ngakak! (KD.KAB/hal.11)

Kata ngakak merupakan bahasa gaul dari kata mengakak, proses afiksasi yang seharusnya kata dasar mendapat imbuhan prefiks men- \{men- + ngakak\} mengakak berubah menjadi ng- \{ng-+ ngakak $\}$ ngakak. Jadi, bentuk perubahan dalam bahasa gaul terdapat pada prefiks yang seharusnya berimbuhan $\{$ men- $\}$ berubah menjadi $\{$ ng- $\}$ pada bahasa gaul.

Cewek kayak si oneng pasti yang ngantri berjibun, tampang paling gak kayak ari wibowo dan pasti naik mobil keren.(KD.AAMC/hal.21) 
Kata ngantri merupakan bahasa gaul dari mengantri dari kata dasar antri, proses afiksasi yang harusnya $\{$ men-+antri $\}$ mengantri berubah menjadi $\{$ ng-+antri $\}$ ngantri pada bahasa gaul. Jadi, bentuk perubahan dalam bahasa gaul terdapat pada prefiks yang seharusnya berimbuhan $\{$ men- $\}$ berubah menjadi $\{$ ng- $\}$ pada bahasa gaul.

\section{Afiksasi bahasa gaul $\{n y-\}+K D$}

Terdapat perubahan pada prefiks yang seharusnya $\{$ men- $\}$ menjadi $\{$ ny- $\}$ selain itu beberapa kosakata disertai perubahan pada fonem $a$ menjadi fonem $e$ dalam bahasa gaul, seperti berikut:

Tangan adik bontot gue itu udah duluan nyamber gelas gue, (KD.AAMC/hal 14)

Danang yang duduk dibelakang engkong leman nyeletuk, gue mendelik. (KD.AAMC/Hal.16)

Kata nyeletuk merupakan bahasa gaul dari kata menceletuk berasal dari kata celetuk, harusnya proses afiksasi yang seharusnya $\{$ men- + celetuk $\}$ mencari berubah menjadi \{ny-+celetuk\} nyeletuk. Jadi, pada prefiks yang seharusnya $\{$ men- $\}$ berubah menjadi $\{$ ny- $\}$.

\section{Afiksasi bahasa gaul $\{n-\}+K D+\{-i n\}$}

Terdapat perubahan pada konfiks yang seharusnya $\{$ men-i $\}$ menjadi $\{n-i n\}$ selain itu beberapa kosakata disertai perubahan pada fonem $a$ menjadi fonem $e$ dalam bahasa gaul, seperti berikut:

Nemenin gue ngerapih-rapihin arsip, mahmud aja mau nemenin gue kok. (KD.PKA/30)

Kata nemenin merupakan bahasa gaul dari menemani dari kata teman. Proses afiksasi seharusnya $\{$ men-+teman+-i $\}$ menemani berubah menjadi $\{n-+$ teman+-in $\}$ nemenin. Vokal $a$ berubah menjadi vokal $e$. 


\section{Afiksasi bahasa gaul $\{m\}+K D+\{$ in $\}$}

Terdapat perubahan pada konfiks yang seharusnya $\{$ men-+-i/-kan $\}$ menjadi $\{n-$ in ) selain itu beberapa kosakata disertai perubahan pada fonem $a$ menjadi fonem $e$ dalam bahasa gaul, seperti berikut:

Pernah juga mandangin dari balik pinggung temannya yang berdiri diantara gue ama si oneng.(KD.AAMC/Hal.21)

Kata mandangin merupakan bahasa gaul dari memandangi dari kata pandang. Proses afiksasi seharusnya \{men-+pandang+-i\} memandagi berubah menjadi \{m+pandang+-in $\}$ mandangin. Konfiks $\{$ men-i $\}$ berubah menjadi $\{m-i n\}$.

Iya gue nyesel duit ambles kena tampar lagi, eh jadi gak minjemin gua gocap.(KD.KAB/Hal 12)

Kata minjemin merupakan bahasa gaul dari meminjami dari kata pinjam. Proses afiksasi seharusnya $\{$ men-+pinjam+-i $\}$ meminjami berubah menjadi $\{\mathrm{m}$ +pinjam+-in $\}$ minjemin. Konfiks $\{$ men-i $\}$ berubah menjadi $\{m-i n\}$.

\section{Afiksasi bahasa gaul $\{$ ng $\}+K D+i n$}

Ditemukan perubahan afiks pada proses afiksasi pada bahasa gaul dalam novel Ayat Amat Cinta karya Asma Nadia, Boim Lebon, dkk. Terdapat perubahan pada konfiks yang seharusnya $\{$ men-+-i/-kan $\}$ menjadi $\{n-i n\}$, seperti berikut:

Gue pura-pura aja pasang tampang antusias, dan siap-siap ngucapin terimakasih. (KD.AAMC/H.15)

Kata ngucapin merupakan bahasa gaul dari mengucapkan dari kata ucap. Proses afiksasi seharusnya \{men-+ucap+-kan\} mengucapkan berubah menjadi \{ng-+ucap+in ngucapin. Konfiks $\{$ men-kan $\}$ berubah menjadi $\{$ ng-in $\}$.

Gue bukan nggak berusaha ngilangin sifat pemalu gue yang overdosis dan sering ngilangin kesempatan emas. (KD.AAMC/H.17)

Kata ngilangin merupakan bahasa gaul dari menghilangkan dari kata hilang. Proses afiksasi seharusnya \{men-+hilang+-kan\} menghilangkan berubah menjadi \{ng-+hilang+-in $\}$ ngilangin. Konfiks \{men-kan\} berubah menjadi \{ng-in\}. 


\section{Afiksasi bahasa gaul $\{$ nge- $\}+K D+-i n$}

Terdapat perubahan pada konfiks yang seharusnya $\{$ men-+-i/-kan $\}$ menjadi $\{n-$ in\} dan beberapa kata mengalami perubahan fonem $a$ menjadi fonem $e$, seperti berikut:

Untunglah nyaksama babe rajin ngebujukin sehingga as a baby gue akhirnya pelan-pelan melek dan melihat dunia. (KD.AAMC/H.13)

Kata ngebujukin merupakan bahasa gaul dari membujukin dari kata bujuk. Proses afiksasi seharusnya \{men-+bujuk+-i membujuki berubah menjadi \{nge-+bujuk+-in ngebujukin. Konfiks yang seharusnya \{men-i\} berubah menjadi \{nge-in\}.

Susah banget ngeluarin omongan dari mulut, cuma dada gue doing yang naik turun. (KD.AAMC/H.15)

Kata ngeluarin merupakan bahasa gaul dari mengeluarkan dari kata keluar. Proses afiksasi seharusnya \{men-+keluar+-kan\} mengeluarkan berubah menjadi \{nge-+keluar+-in $\}$ ngeluarin. Konfiks yang seharusnya $\{$ men-kan $\}$ berubah menjadi \{nge-in $\}$.

\section{Afiksasi bahasa gaul $\{n y\}+K D+i n$}

Ditemukan perubahan afiks pada proses afiksasi pada bahasa gaul dalam novel Ayat Amat Cinta karya Asma Nadia, Boim Lebon, dkk. Terdapat perubahan pada konfiks yang seharusnya $\{$ men-+-i/-kan $\}$ menjadi $\{n-i n\}$ dan beberapa kata mengalami perubahan fonem $a$ menjadi fonem $e$, seperti berikut:

Ayat, lo suka nggak nich...? tanya kong laman sambil tangannya nyodorin tasbih. (KD.AAMC/H.15)

Kata nyodorin merupakan bahasa gaul dari menyodorkan dari kata sodor. Proses afiksasi seharusnya \{men-+sodor+-kan\} menyodorkan berubah menjadi \{ny+sodor+-in $\}$ nyodorin. Konfiks \{men-kan\} berubah menjadi \{ny-in $\}$.

\section{Afiksasi bahasa gaul $\{$ be- $\}+K D$}


Ditemukan perubahan afiks pada proses afiksasi pada bahasa gaul dalam novel Ayat Amat Cinta karya Asma Nadia, Boim Lebon dkk. Terdapat perubahan pada prefiks yang seharusnya $\{$ ber- $\}$ menjadi $\{$ be- $\}$, seperti berikut:

Soalnya kalau gelengannya kenceng, bisa patah tuh leher,hi hi.. nggak ding becanda (KD.PAAC/H.272)

Kata becanda merupakan bahasa gaul dari kata bercanda dari kata canda. Proses afiksasi yang seharusnya adalah $\{$ ber-+canda $\}$ bercanda berubah menjadi $\{$ be- + canda $\}$ becanda. Jadi, prefiks yang harusnya $\{$ ber- $\}$ berubah menjadi $\{$ be- $\}$ dalam bahasa gaul.

\section{Afiksasi Bahasa Gaul $\{d i-\}+K D+\{-i n\}$}

Ditemukan perubahan afiks pada proses afiksasi pada bahasa gaul dalam novel Ayat Amat Cinta karya Asma Nadia, Boim Lebon dkk. Terdapat perubahan pada konfiks yang seharusnya $\{$ di-+-i/-kan $\}$ menjadi $\{$ di-in $\}$, seperti berikut:

Gue tahu nggak boleh dibiarin begini, harus diakhiri.(KD.AMC/hal.23)

Kata dibiarin merupakan bahasa gaul dari kata dibiarkan dari kata biar, proses afiksasi yang seharusnya adalah \{di-+biar+kan $\}$ dibiarkan berubah menjadi \{di+biar+-in\} dibiarin. Jadi, konfiks yang seharusnya $\{$ di-kan $\}$ berubah menjadi $\{$ di-in $\}$.

Dari mulai jendela, balik pintu, dibalik karpet, di kolong kulkas di balik gorden, sampe ke atas anak diperiksain satu-satu. (KD.PKA/hal29)

Kata diperiksain merupakan bahasa gaul dari kata diperiksakan dari kata periksa. Proses afiksasi yang seharusnya adalah $\{$ di-+periksa+kan $\}$ diperiksakan berubah menjadi \{di-+periksa+-in\} diperiksain. Jadi, konfiks yang seharusnya \{di-kan\} berubah menjadi $\{$ di-in $\}$.

\section{Afiksasi Bahasa Gaul $\{k e\}+K D$}

Ditemukan perubahan afiks pada proses afiksasi pada bahasa gaul dalam novel Ayat Amat Cinta karya Asma Nadia, Boim Lebon dkk. Terdapat perubahan pada prefiks yang seharusnya $\{$ ter- $\}$ menjadi $\{k e-\}$, seperti berikut: 
Suara cing sarip yang keras, bikin gue kaget dan buru-buru dengan ngeraih gelas, lagian harusnya udah nggak ketahan juga sih.(KD.AAMC/hal.14)

Kata ketahan merupakan bahasa gaul dari tertahan dari kata tahan. Proses afiksasi yang seharusnya $\{$ ter-+tahan $\}$ tertahan berubah menjadi $\{$ ke-+tahan ketahan. Jadi, terdapat perubahan pada prefiks yang seharusnya $\{$ ter- $\}$ berubah menjadi $\{$ ke $\}$.

Terang aja nggk ada orang, dia ngebuka pintu sambil merem, gitu? Terang nia ramah tamah sambil nahan ketawa karena melihat arman yang super penakut itu. (KD.PKA/hal.34)

\section{Reduplikasi}

Reduplikasi bahasa gaul yang digunakan dalam Novel Ayat Amat Cintakarya Asma Nadia, Boim Lebon dkk ini adalah reduplikasi penuh, reduplikasi sebagian, reduplikasi dengan afiksasi, reduplikasi perubahan bunyi (fonem).

\section{Reduplikasi Seluruh Bahasa Gaul}

Reduplikasi Bahasa Gaul keseluruhan Dalam Novel Ayat Amat Cinta karya Asma Nadia, Boim Lebon dkk. Reduplikasi bahasa gaul yang digunakan dalam Novel Ayat Amat Cinta karya Asma Nadia, Boim Lebon dkk ini adalah reduplikasi penuh morfem dasar yang mendapat pengulangan keseluruhan pada morfem Ulang (MDMU\} beberapa mengalami perubahan fonem a menjadi fonem e pada morfem bahasa gaul, seperti berikut.

Paling-paling, lo abis ngambil majalah di agen! Hari ini banyak yang laku gak.(KD.KAB/hal.6)

Kata paling-paling merupakan reduplikasi seluruh yang dibentuk oleh kata dasar paling yang diulang secara keseluruhan yang maknanya adalah mungkin. Jadi, reduplikasi dari morfem dasar Paling mendapat pengulangan keseluruhan pada morfem ulang $\{\mathrm{MD}-\mathrm{MU}\}$.

Dalam hati gue udah ngangguk-ngangguk dan teriak mau kong! (KD.AAMC/hal.15) 
Kata ngangguk-ngangguk merupakan reduplikasi seluruh yang dibentuk oleh morfem dasar ngangguk yang maknanya mengangguk berulang kali. Morfem dasar ngangguk berasal dari kata dasar angguk mendapat imbuhan \{me-\} mengangguk, namun dalam bahasa gaul imbuhan berubah $\{$ ng- $\}$. Jadi, morfem ngangguk mendapat morfem ulang ngangguk $\{$ MD-MU $\}$.

Tapi ekor kudanya bener-bener bikin tampangnya yang item manis itu tampak inocent dan gak berdaya (KD.AAMC/hal.19).

Kata bener-bener merupakan reduplikasi seluruh yang dibentuk oleh kata dasar benar yang mengalami perubahan fonem $a$ berubah menjadi $e$ menjadi bener mendapat pengulangan seluruh $\{\mathrm{MD}-\mathrm{MU}\}$ menjadi bener-bener yang maknanya adalah sungguhan.

\section{Reduplikasi Sebagian Bahasa Gaul}

Reduplikasi bahasa gaul yang digunakan dalam Novel Ayat Amat Cinta karya Asma Nadia, Boim Lebon dkk ini adalah bentuk pengulangan reduplikasi sebagian dari bentuk morfem dasarnya.

Malah akibatnya kebawa-bawa sampai sekarang. (KD.AMC/hal.188)

Kata kebawa-bawa merupakan bentuk reduplikasi sebagian dari morfem kebawa (morfem dasar kebawa + morfem ulang bawa).

Gak ada lima menit sebuah bus patas yang penumpangnya berjubel sampai keluar-luar pintu, berhenti. (KD.PAAC/hal.276)

Kata keluar-luar merupakan bentuk reduplikasi sebagian dari morfem keluar (morfem dasar keluar+morfem ulang luar).

\section{Reduplikasi dengan afiksasi}

Reduplikasi dengan afiksasi bahasa gaul yang digunakan dalam Novel Ayat Amat Cinta karya Asma Nadia, Boim Lebon dkk ini adalah reduplikasi yang disertai penambahan sufiks $\{$-an. $\}$, sufiks $\{-$ in $\}$, seperti berikut. 
Seniman tak laku, si bejo, ikut-ikutan mendramatisir, jelas jamal tidak menerima! (KD.ATC/hal.152)

Kata ikut-ikutan merupakan bentuk reduplikasi yang disertai dengan afiksasi dari morfem dasar ikut (morfem dasar ikut + morfem ulang ikut + afiks - an).

Iye, klo perlu bawa antar-antaran jangan ketinggalan juge roti buaya yang gede.(KD.AAC/hal.61)

Kata antar-antaran merupakan bentuk reduplikasi yang disertai dengan afiksasi dari morfem dasar antar (morfem dasar antar + morfem ulang antar + afiks - an).

\section{Reduplikasi Perubahan fonem}

Reduplikasi dengan perubahan fonem bahasa gaul yang digunakan dalam novel Ayat Amat Cinta karya Asma Nadia, Boim lebon dkk merupakan reduplikasi yang disertai perubahan fonem.

Bocah ingusan itu sekarang udah kuliah tingkat satu, dan udah gonta-ganti cewek. (KD.AAMC/hal.23)

Kata gonta-ganti merupakan bentuk reduplikasi dengan perubahan fonem dari bentuk gantian yang maknanya banyak. Pada reduplikasi terdapat perubahan fonem $o$ dan $a$ menjadi fonem adan i pada pengulangan.

Ia tau kalau gue komat-kamit bertasbih. (KD.KAB/hal.11)

Kata komat-kamit merupakanbentuk reduplikasi dengan perubahan fonem dari bentuk berkomat yang maknanya berbicara tanpa suara. Pada reduplikasi terdapat perubahan fonem $o, a$ menjadi fonem $a, i$ pada pengulangan.

Mang ayat di sini (kulihat mang ayat dengan baju compang-camping tertawa lebar berkacak pinggang). (KD.MA/hal.69)

Kata compang-camping merupakan bentuk reduplikasi dengan rubahan fonem dari bentuk bercompangan yang maknanya tidak karuan. Pada reduplikasi terdapat Perubahan fonem $o, a$ menjadi fonem $a, i$ pada pengulangan.

\section{Pemendekan kata}


Pemendekan kata bahasa gaul dalam novel Ayat Amat Cinta karya Asma Nadia, Boim Lebon dkk merupakan pemendekan kata berupa penggalan, singkatan, dan akronim.

\section{Pemendekan kata berupa penggalan bahasa gaul}

Pemendekan kata bahasa gaul dalam novel Ayat Amat Cinta karya Asma Nadia, Boim Lebon dkk merupakan bentuk penggalan pada satu atau dua suku kata bagian depan, seperti berikut.

Ahh ....gue belum komen soal rambutnya kan? Andra mengangguk. (KD.KTA/hal.161)

Kata komen merupakan penggalan dari komentar.

Nggak konsen karena teriakan mang ayat yang terus terdengar.(KD.MA/hal.77)

Kata konsen merupakan penggalan dari konsentrasi.

\section{Pemendekan kata berupa singkatan bahasa gaul}

Pemendekan kata berupa singkatan bahasa gaul dalam novel Ayat Amat Cinta karya Asma Nadia, Boim Lebon dkk merupakan bentuk singkatan dari satu fonem pertama pada setiap kata.

Bener sih mestinya sebagai cowok gue harus lebih pede. (KD.AAMC/hal.13)

Kata pede merupakan singkatan dari kata percaya diri.

Bersama dengannya dari kelas enam SD sampai jadi mahasiswa, mencoba setia pdkt sampai gak kenal lelah ampe muke tembok sudah dapat.(KD.CS/hal.302)

Kata $p d k t$ merupakan singkatan dari kata pendekatan.

Map om, komdektur yang baik ujar iyan yang meskipun Cuma lulusan S2 tapi selalu ingat sama ajaran guru ngajinya supaya tetap ramah kepada siapapun.(KD.PAAC/Hal.275)

\section{Pemendekan kata berupa akronim bahasa gaul}


Pemendekan kata berupa akronim bahasa gaul dalam novel Ayat Amat Cinta karya Asma Nadia, Boim Lebon dkk merupakan bentuk akronim yang di bentuk dari unsur satu atau dua atau suku pertama atau suku terakhir atau satu fonem pertama.

Penghasilan sedikit-sedikit cukuplah buat sementara dari mengejar bimbel dan privat. (KD.ATC/hal.159)

Kata bimbel dibentuk oleh dua morfem bim yang berarti bimbingan dan bel yang berarti belajar.

Gak lagi dugemsama nena, elsa, bianka atau teman-teman ceweknya yang genit itu. (KD.GPA/hal.206)

Kata dugem dibentuk dari dua morfem, yaitu $d u$ yang berarti dunia dan gem yang berarti gemerlap.

\section{PENUTUP}

Sesuai dengan masalah penelitian ini, hasil penelitian ini mencangkup tiga hal utama, yaitu afiksasi bahasa gaul, reduplikasi bahasa gaul, dan pemendekan kata bahasa gaul yang terdapat pada novel Ayat Amat Cinta karya Asma Nadia, Boim Lebon dkk.

Proses pembentukan kata bahasa gaul dalam novel Ayat Amat Cinta karya Asma Nadia, Boim Lebon dkk. Dihasilkan sejumlah kata yang dijadikan sebagai deskripsi morfologis bahasa gaul dalam novel Ayat Amat Cinta karya Asma Nadia, Boim Lebon dkk. tersebut sesuai dengan penelitian ini berupa afiksasi, reduplikasi, dan pemendekan kata. Sebagai berikut:

1. Afiksasi yang dipakai dalam pembentukan kata bahasa gaul padanovel Ayat Amat

Cinta karya Asma Nadia, Boim Lebon dkk, merupakan (a) afiksasi dalam bentuk kata kerja aktif dan pasif, serta (b) afiks pembentuk kata kerja aktif meliputi $\{\mathrm{N}-$, be- \}, \{N-/-in $\}$ seperti yang terdapat pada kata kenalin, siapin, lakuin dan sebagainya. (c) Pembentukan afiksasi pada bahasa gaul terdapat perubahan pembentukan yang seharusnya yaitu prefiks \{men- $\}$ menjadi bentuk\{n-, m-, ng-, ny- \} seperti terdapat pada kata nekat, mukul, ngambil, ngerusak, nyari dan sebagainya. (d) Pada pembentukan afiksasi bahasa gaul, terdapat perubahan pada 
konfiks $\{$ men- + -kan/-i $\}$ berubah menjadi $\left\{n-, m_{-}\right.$, ng-, ny- $\left.+\{-i n\}\right\}$ seperti kata nemenin, mandangin, ngilangin, ngebujukin, nyodorin dan sebagainya. (e) Prefiks $\{$ ber- $\}$ juga berubah menjadi $\{$ be- $\}$ seperti pada kata bercanda menjadi becanda. Sedangkan bentuk kata kerja pasif bahasa gaul yaitu konfiks $\{$ di-+in $\}$ dan prefiks $\{k e-\}$. Prefiks $\{$ di- $+-k a n / i\}$ berubah menjadi $\{$ di- +- in $\}$ dan prefiks $\{$ ter- $\}$ berubah menjadi $\{k e\}$. Dan sufiks yang seharusnya $\{k a n-\}$ berubah menjadi $\{$-in $\}$

2. Reduplikasi bahasa gaul dalamnovel Ayat Amat Cinta karya Asma Nadia, Boim Lebon dkk. merupakan reduplikasi seluruh (penuh), reduplikasi sebagian, reduplikasi dengan afiksasi dan reduplikasi perubahan fonem serta diikuti gejala fonologis seperti paling-paling, kebawa-bawa, ikut-ikutan, dan komat-kamit.

3. Pemendekan kata bahasa gaul dalam novel Ayat Amat Cinta karya Asma Nadia, Boim Lebon dkk. adalah pemendekan berupa penggalan, singkatan dan akronim seperti komen, pede, bimbel, dan sebagainya.

\section{DAFTAR RUJUKAN}

Alwi, Hasan, Dkk.2000. Tata Bahasa Baku Bahasa Indonesia. Jakarta: Balai Pustaka

Chaer, Abdul. 2015. Morfologi Bahasa Indonesia. Jakarta: PT Rineka Cipta.

Krindalaksana, Harimurti. 2001. Ksmus Linguistik (edisi tiga). Jakarta: Gramedia Pustaka.

Muslich, Masnur. 2010. Perencanaan Bahasa pada Era Globalisasi. Jakarta: PT Bumi Aksara.

Moentaha, Salihen. 2006. Bahasa dan Terjemahan. Jakarta: Kesaint Blanc.

Moleong, Lexy J. 2011. Metodologi Penelitian Kualitatif. Bandung: PT. Remaja Rosda Karya.

Nadia, Asma, dkk. 2010. Ayat Amat Cinta. Jakarta: PT. Lingkar Pena Kreativa Presents.

Rosidi, Ajip. 2010. Bahasa Gaul. (online) didapat dari :https://rubrikbahasa.wordpress.com/2010/06/05/bahasa-gaul. diakses 05 juni 2010.

Setiawan, Robi. 2017. Ragam Teori Pemendekan Kata.(online) didapat dari: https://robisetya.wordpress.com/2017/12/19/ragam-teori-pemendekan-kata. diakses 19 desember 2017. 
Sugiyono. 2014. Metode Penelitian: Kualitatif, Kuantitatif, dan R\&D. Bandung: Alfabeta.

Soeparno. 2003. Dasar-dasar Linguistik Umum. yogyakarta: PT Tiara wacana yogyakarta.

Wijana, I Dewa Putu. 2010. Bahasa Gaul Remaja Indonesia. Yogyakarta: Aditya Media Publishing.

Verhaar, JWM. 2012. Asas-Asas Linguistik Umum. Yogyakarta: Gajah Mada University. 